\title{
Methane Emissions and Rice Yield in Rainfed Bed System (Surjan) as Affected by Manure and Zeolite Treatment
}

\author{
DOI: 10.18196/pt.2019.105.141-146
}

\author{
Anggri Hervani*, Helena Lina Susilawati, Anicetus Wihardjaka \\ Agricultural Environment Research Institute, Pati, Central of Java, 59182, Indonesia \\ *Coresponding author, email: anggrihervani@pertanian.go.id
}

\begin{abstract}
Rainfed area as one of rice production areas is facing drought due to climate change. Management of rainfed area is needed due to its contribution, in addition to the production of rice, in producing methane as a contributor to greenhouse gas emission. This research aimed to investigate the methane emission status and yield from rainfed rice system with manure and zeolite treatment on the bed system (surjan). The doses of manure were 5, 15 and 30 tons/ha and the zeolite was 1 and 2.5 tons/ha. The result showed that all treatment had no significant effect on daily methane fluxe and grain yield in surjan system. However, the combination of manure at 15 tons/ha with zeolite at 1 ton/ha promoted higher methane emissions (63.43 kg CH./ha/ season). In addition, the combination treatment of manure at 5 tons/ha with zeolite at 2.5 tons/ha contributed to obtain higher grain yield (6.9 tons/ha).

Keywords: Methane emission; Rainfed; Surjan
\end{abstract}

\section{ABSTRAK}

Sebagai salah satu areal produksi padi, lahan tadah hujan menghadapi cekaman kekeringan karena perubahan iklim. Manajemen lahan tadah hujan diperlukan karena selain sebagai lokasi produksi padi namun juga sebagai lokasi yang menghasilkan emisi gas rumah kaca khususnya metana. Penelitian ini bertujuan untuk menginvestigasi emisi metana dan hasil gabah padi dari sistem pertanaman surjan dengan perlakuan pupuk kandang (pukan) dan zeolit. Dosis pukan yang digunakan yaitu 5, 15 dan 30 ton/ha sedangkan dosis zeolit yang digunakan yaitu 1 dan 2.5 ton/ha. Hasil penelitian menunjukkan bahwa semua perlakuan tidak berpengaruh terhadap fluks metana harian dan gabah kering panen dari lahan surjan. Kombinasi perlakuan pukan dosis 15 ton/ha dengan zeolit 1 ton/ha mengemisikan metana lebih tinggi dibandingkan kombinasi perlakuan lain sebesar 63.43 kg CH./ha/musim. Gabah kering panen (GKP) maksimum didapatkan pada kombinasi perlakuan pukan 5 ton/ha dengan zeolit 2.5 ton/ha seberat 6.9 ton/ha.

Kata Kunci: Emisi metana; Tadah hujan; Surjan

\section{INTRODUCTION}

Rainfed is one of the rice production systems that contribute to provide rice yield. However, rainfed known as a suboptimal area facing drought. The characteristics of rainfed area are low soil fertility level and unpredictable rainfall pattern that promotes risk under drought condition (Mulyadi and Wihardjaka, 2014). Regarding the climate change issue, the rainfed area is getting marginalized. Concerning on this issue, farmers from rainfed area adopt bed farming system (surjan) to develop soil productivity and obtain the diverse crop yield while as an adaptation action to climate change.

Bed farming system is common local wisdom in the coastal area that manages the rice field due to the bad drainage system. The bad drainage system is caused by the geomorphology rainfed area that is a fluviomarine plain and a former of a black swamp (Marwasta and Priyono, 2007). According to Aminatun et al. (2014), the bed farming system is called surjan since the rice field pattern looks like the lines pattern on the traditional clothes of Javanese (surjan). These lines are formed from terrestrial at high level and aquatic grooves at a low level. The terrestrial parts are planted with secondary crops or horticulture, while the aquatic grooves are planted with rice. Therefore, the surjan ecosystem is different from the general rice field. The great function of surjan is to store water from rainfall and runoff for water supply system during rice growth.

Zeolite is a naturally crystalized aluminosilicate used as ameliorant in the rice field to develop cation exchange capacity that promotes yield and support nutrient efficiency (Ramesh and Reddy, 
2011). Moreover, zeolite treatment is able to increase protein quality of rice, develop nitrogen efficiency and, in the long-term application, promote recovery of soil nitrogen level (Sepaskhah and Barzegar, 2010). The application of manure as organic fertilizer is an effort to develop the carbon sequestration for climate change mitigation scenario, to increase fertility, chemical, physical, and biological properties of the soil, to develop agronomic performance and to increase the yield as well as to enhance the soil organic nitrogen content (Diacono and Montemurro, 2011; Mulyadi and Wihardjaka, 2014). However, manure and other organic material as a soil amendment in rice field contributes to the increase in methane emissions (Dendooven et al., 2012).

Agriculture sector is one of the sources of greenhouse gas $(\mathrm{GHG})$ emissions especially methane $\left(\mathrm{CH}_{4}\right)$, dinitro oxide $\left(\mathrm{N}_{2} \mathrm{O}\right)$ and carbon dioxide $\left(\mathrm{CO}_{2}\right)$, in which each gas contributes $15 \%, 6 \%$ and $55 \%$ of the total emissions, respectively (Mosier et al., 1994). Rainfed as part of agriculture ecosystem also plays a role as a source of emission releasing the GHG to the atmosphere. Appropriate technology is needed to reduce GHG emissions from rainfed rice system. This study aimed to determine the level of $\mathrm{CH}_{4}$ gas emissions from rainfed rice field in the surjan system treated with manure and zeolite.

\section{MATERIALS AND METHODS}

The research was conducted in the Indonesian Agricultural Environment Research Institute field trial during the rainy season in 2012. The experiment was carried out on a plot trial with the plot size of $6 \mathrm{~m} \times 46.5 \mathrm{~m}$ using rice $\mathrm{cv}$. Ciherang grown at the aquatic grooves of surjan. Meanwhile, the terrestrial area of surjan with a size of $2 \mathrm{~m} \times 46.5$ $\mathrm{m}$ was used to grow mango (Figure 1). The surjan cross-section consisted of the aquatic grooves as a subsoil (tabukan part) in a high bulk density, planted with rice, and the terrestrial part/topsoil

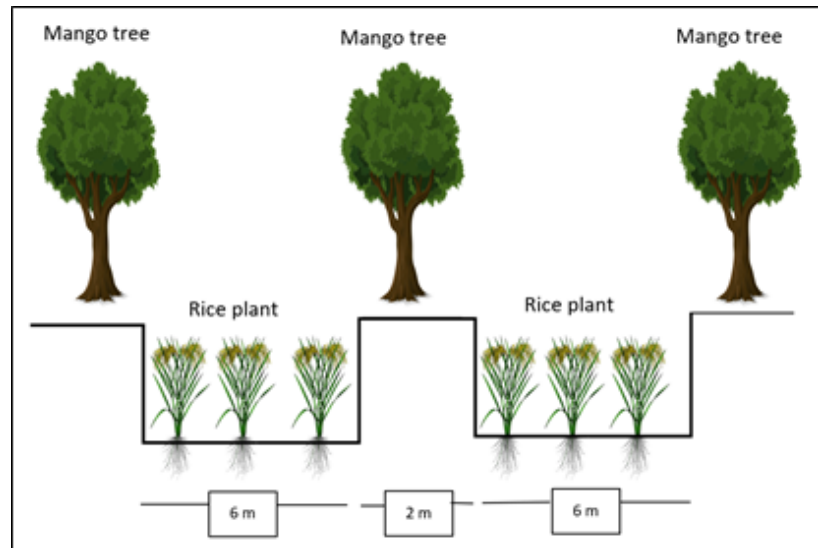

Figure 1. Agricultural Plan of the Surjan System of Rice with Mango Trees in Rainfed Areas

(guludan part), planted with mango (Wihardjaka dan Indratin, 2002).

There were combination treatments between manure and zeolite. The manure application rates were $5,15,30$ tons/ha, while the zeolite treatment rates were 1 and 2.5 tons/ha. Manure and zeolite were applied at the beginning of planting time. The basalt fertilizer, such as urea was applied at a dose of $250 \mathrm{~kg} / \mathrm{ha}$ in each plot with leaf color chart as guidance. The dose of. $\mathrm{P}_{2} \mathrm{O}_{5}$ was $36 \mathrm{~kg} /$ ha applied at the beginning of planting along with the application of manure and zeolite. Meanwhile, $\mathrm{K}_{2} \mathrm{O}$ was applied at a dose of $60 \mathrm{~kg} / \mathrm{ha}$, twice in one planting season. The first application of $\mathrm{K} 2 \mathrm{O}$ fertilizer was $30 \mathrm{~kg} / \mathrm{ha}$ at the beginning of planting along with $\mathrm{P}_{2} \mathrm{O}_{5}$, manure and zeolite application, while the second application was at 39 Days After Transplanting (DAT). The variables observed were grain yield ((gabah kering panen (GKP)) at 14\% water content and methane emissions from surjan in the rainfed system. The grain yield was obtained by using harvest sampling area with a size of $2.5 \times 2.5 \mathrm{~m}$. The sampling of $\mathrm{CH}_{4}$ emissions was performed by capturing the air samples using a closed chamber method with a dimension of $50 \mathrm{~cm} \times 50 \mathrm{~cm} \times 103$ $\mathrm{cm}$. The three-time interval for gas sampling were 10,20 , and 30 minutes. The gas was taken from the chamber using a $10 \mathrm{ml}$ of syringe then the methane was analyzed by Gas Chromatography $8 \mathrm{~A}$ which 
has an FID detector (Flame Ionization Detector) to analyze $\mathrm{CH}_{4}$ concentration. The $\mathrm{CH}_{4}$ gas was observed 3 (three) times in 1 (one) growing season according to the growth development phase of rice plants. The Global Warming Potential (GWP) of methane was calculated using the $\mathrm{CO}_{2}$ equivalent weight ( $\mathrm{kg} \mathrm{CO}$ eq/ha). The potential radiative value of methane, as a relative value to $\mathrm{CO}_{2}$, was used at 25 (Houghton et al., 2001).

According to Khalil et al. (1991), the methane emissions from methane concentration can be calculated using the equation:

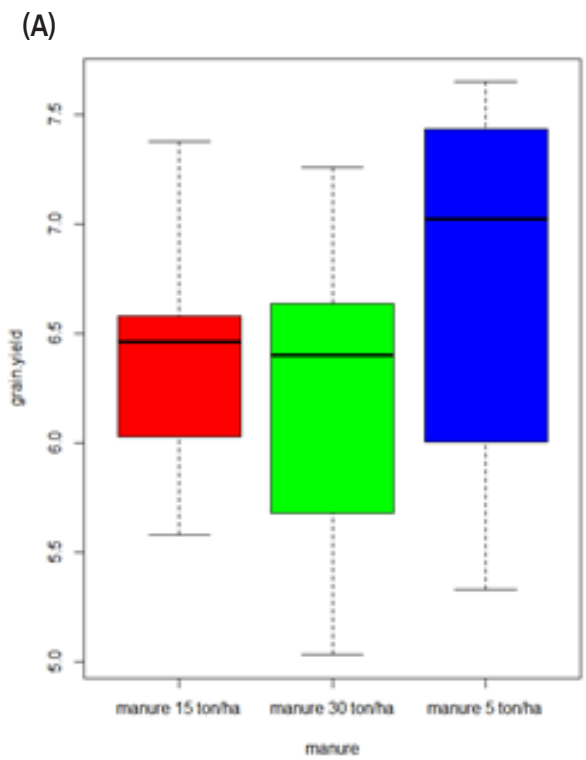

(B)

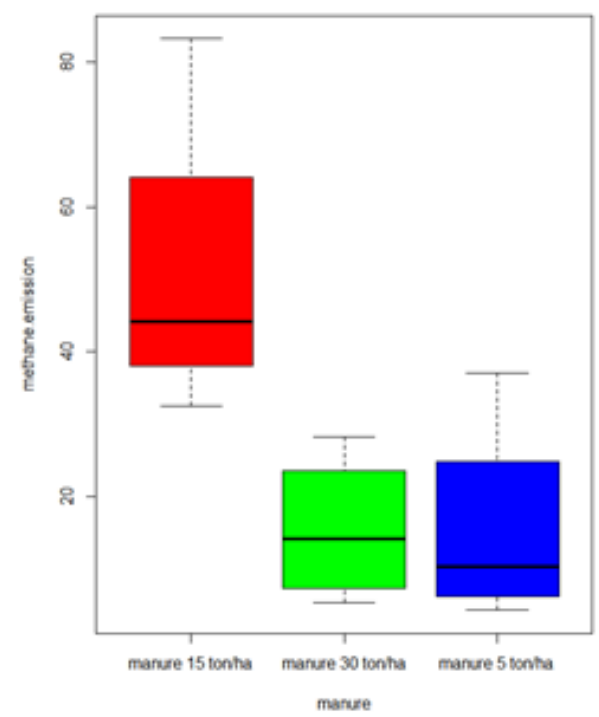

$$
F=\frac{d c}{d t} \times \frac{V c h}{A c h} x \frac{m W}{m V} x \frac{273,2}{(273,2+T)}
$$

Annotation:

F : Flux of methane $\left(\mathrm{mg} / \mathrm{m}^{2} /\right.$ minute $)$

$\mathrm{dc} / \mathrm{dt}$ : Slope concentration of methane/time sampling (ppm/minute)

Vch: Volume of the chamber $\left(\mathrm{m}^{3}\right)$

Ach : Base area of the chamber $\left(\mathrm{m}^{2}\right)$

$\mathrm{mW}$ : The molecule weight of methane $(\mathrm{g})$

$\mathrm{mV}$ : The molecule volume of methane (22.41 1)

$\mathrm{T}$ : Average temperature during gas sampling $\left({ }^{\circ} \mathrm{C}\right)$
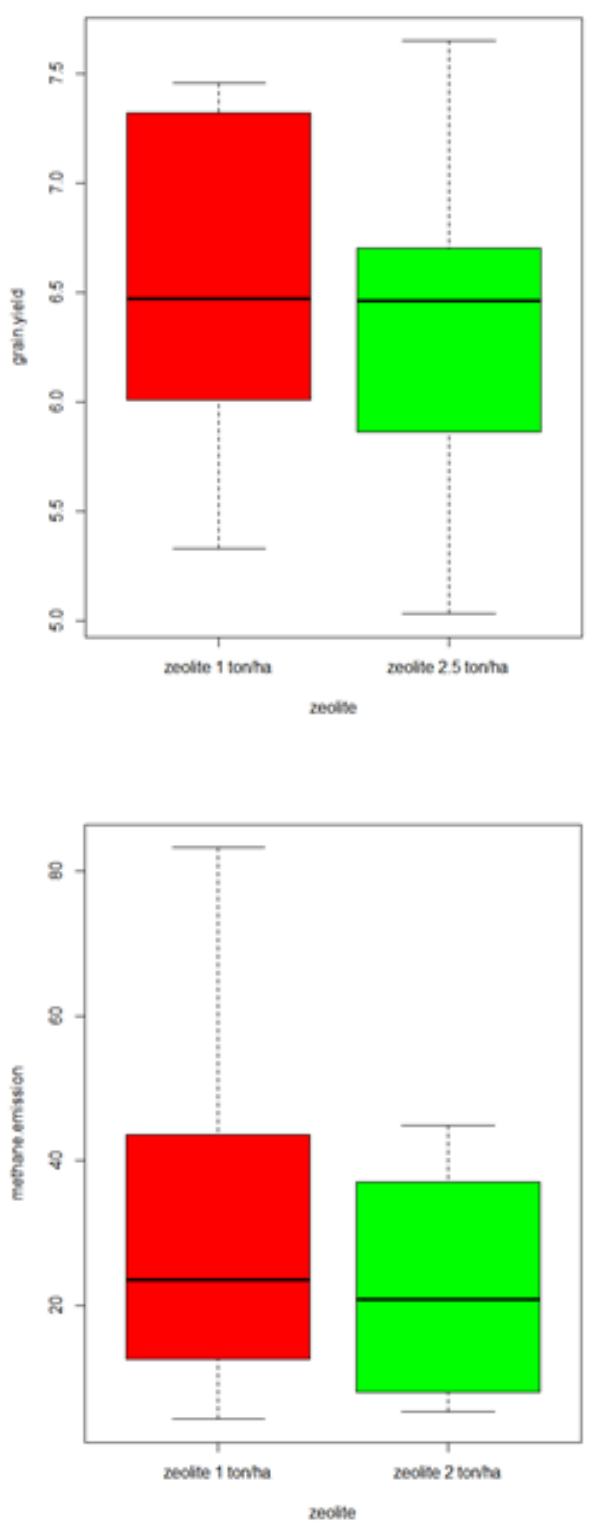

Figure 2. Boxplot FF ANOVA of the Effect of Manure and Zeolite Treatment on Methane Emissions (A) and Grain Yield (GKP) (B) 


\section{Data Analysis}

For statistical analysis, the $\mathrm{R}$ Studio (version 3.2.1) was used to analyze the data. The Levene test and Shapiro-Wilk was used to analyze the homogeneity and normality distribution of the parametric data. Meanwhile, FF ANOVA was used to analyze methane emission and yield. Post hoc test was used to examine the differences between the treatment.

\section{RESULS AND DISCUSSION}

There was no significant interaction effect between manure and zeolite on the methane emissions ( $F=1.8 ; d f=2 ; P=0.24)$. Based on the statistical tests (FF ANOVA), manure had a significant effect on $\mathrm{CH}_{4}$ emissions $(\mathrm{F}=7.39 ; \mathrm{df}=2 ; \mathrm{P}=$ 0.24), while zeolite did not significantly affect $\mathrm{CH}_{4}$ emissions $(\mathrm{F}=1.06 ; \mathrm{df}=1 ; \mathrm{P}=0.34$ ) (Figure 2a). The post hoc test at $95 \%$ level showed that manure treatment at 5 tons/ha $(\mathrm{P}=0.01)$ and at 30 tons/ ha $(\mathrm{P}=0.03)$ significantly affected $\mathrm{CH}_{4}$ emissions from the rice fields with surjan planting system.

The application of manure and zeolite did not significantly affect the daily $\mathrm{CH}_{4}$ flux $(\mathrm{P}>0.05$ ) (Table 1). At 69 DAT, the addition of 2.5 tons/ ha of zeolite showed a smaller $\mathrm{CH}_{4}$ flux compared to the addition of 1 ton/ha of zeolite. The addition of 2.5 tons/ha zeolite was able to suppress $\mathrm{CH}_{4}$ flux by $80 \%, 46 \%$ and $24 \%$ in the treatment of 5 tons/ha, 15 tons/ha, 30 tons/ha of manure at 69 DAT, respectively.

There was no significant interaction effect between manure and zeolite on the grain yield $(\mathrm{F}=$ 1.94; $\mathrm{df}=2 ; \mathrm{P}=0.17)$. Manure treatment $(\mathrm{F}=1.08$; $\mathrm{df}=2 ; \mathrm{P}=0.36)$ and zeolite treatment $(\mathrm{F}=0.37 ; \mathrm{df}$ $=1 . \mathrm{P}=0.55)$ had no significant effect on the grain yield (GKP) (Figure $2 \mathrm{~b})$. The harvested grains in all treatments were between 5.7 to 6.9 tons/ha (Table 2 ). The manure treatment at 5 tons/ha combined with zeolite at 2.5 tons/ha produced grain yield $21 \%$ greater than the treatment of 30 tons/ha
Table 1. Flux of $\mathrm{CH}_{4}$ during three rice plant growth periods as affected by the application of manure and zeolite at various doses

\begin{tabular}{lccc}
\hline Flux $\left(\mathrm{mg} / \mathrm{m}^{2} /\right.$ day $)$ & 40 DAT & 55 DAT & 69 DAT \\
\hline Manure 5 ton/ha + Zeolite 1 ton/ha & 10.65 & 6.65 & 70.65 \\
Manure 5 ton/ha + Zeolite 2.5 ton/ha & 27.15 & 3.25 & 14.15 \\
Manure 15 ton/ha + Zeolite 1 ton/ha & 59.90 & 5.20 & 76.40 \\
Manure 15 ton/ha + Zeolite 2.5 ton/ha & 58.70 & 3.50 & 40.95 \\
Manure 30 ton/ha + Zeolite 1 ton/ha & 29.80 & 3.55 & 35.25 \\
Manure 30 ton/ha + Zeolite 2.5 ton/ha & 3.30 & 8.90 & 26.95 \\
\hline
\end{tabular}

Table 2. Grain yield (GKP) with $14 \%$ water content as affected by the application of manure and zeolite at various doses

\begin{tabular}{lc}
\hline Flux $\left(\mathrm{mg} / \mathrm{m}^{2} /\right.$ day) & Grain yield 14\% (ton/ha) \\
\hline Manure 5 ton/ha + Zeolite 1 ton/ha & 6.461 \\
Manure 5 ton/ha + Zeolite 2.5 ton/ha & 6.992 \\
Manure 15 ton/ha + Zeolite 1 ton/ha & 6.465 \\
Manure 15 ton/ha + Zeolite 2.5 ton/ha & 6.292 \\
Manure 30 ton/ha + Zeolite 1 ton/ha & 6.668 \\
Manure 30 ton/ha + Zeolite 2.5 ton/ha & 5.761 \\
\hline
\end{tabular}

combined with zeolite at 2.5 tons/ ha that produced the lowest grain yield. Treatment of zeolite at 2.5 tons/ha combined with 5 tons of manure tended to increase the grain yield (GKP) significantly than the treatment of zeolite at 1 ton/ha. Similarly, the research result from Al-Jabri, (2009)stated that the application of zeolite combined with manure will increase the grain yield (GKP).

The post hoc test showed that manure treatment at 15 tons/ha combined with Zeolite at 1 ton/ha produced a $\mathrm{CH}_{4}$ emission level that was significantly different from all treatments except the treatment of manure at 15 tons/ha combined with zeolite at 2.5 tons/ha (Table 3). It showed that the treatment of zeolite can reduce methane emissions. Zeolite can be used as an addictive substance to inhibit methane emissions (Mukesh et al., 2016), moreover, zeolite is a cheap ameliorant as a mitigating agent for reducing methane emission (Hui and Chao, 2008). Zeolite, as a stable material, has a capability of storing methane (Joseph et al., 
Table 3. Methane emission, Global Warming Potential (GWP), Global Warming Potential-Yield (GWPy) as affected by the application of manure and zeolite at various doses

\begin{tabular}{|c|c|c|c|}
\hline Flux (mg/m²/day) & $\begin{array}{c}\mathrm{CH}_{4} \\
\mathrm{~kg} \mathrm{CH}_{4} \\
/ \mathrm{ha} / \\
\text { season }\end{array}$ & $\begin{array}{l}\text { GWP } \\
\mathrm{kg} \mathrm{CO}{ }^{-} \\
\text {eq/ ha/ } \\
\text { season }\end{array}$ & $\begin{array}{l}\text { GWPy } \\
\mathrm{kg} \mathrm{CO}_{2}^{-} \\
\text {eq/ ton/ } \\
\text { season }\end{array}$ \\
\hline Manure 5 ton/ha + Zeolite 1 ton/ha & $17.2 \mathrm{~b}$ & 430.3 & 67 \\
\hline Manure 5 ton/ha + Zeolite 2.5 ton/ha & $22.5 b$ & 563.8 & 81 \\
\hline Manure 15 ton/ha + Zeolite 1 ton/ha & $63.4 \mathrm{a}$ & 1585.8 & 245 \\
\hline Manure 15 ton/ha + Zeolite 2.5 ton/ha & $38.6 \mathrm{ab}$ & 966.5 & 154 \\
\hline Manure 30 ton/ha + Zeolite 1 ton/ha & $23.6 \mathrm{~b}$ & 590 & 88 \\
\hline Manure 30 ton/ha + Zeolite 2.5 ton/ha & $7.4 \mathrm{~b}$ & 185.3 & 32 \\
\hline
\end{tabular}

Remarks: Means followed by the same letters in the same column are not significantly different according to post hoc test at a $95 \%$ level.

1983; Eckhard and Matthias, 1997; Myrsini et al., 2014). Therefore, manure amendment to the soil as an organic fertilizer and as a substrate of methanogenesis to produce methane has no significant effect on methane emissions.

\section{CONCLUSION}

All treatments had no significant effect on the daily methane flux and harvested grain yield in the rice field with surjan system. The application of manure at 15 tons/ha combined with zeolite at 1 ton/ha promoted higher methane emission at $63.43 \mathrm{~kg} \mathrm{CH} 4 / \mathrm{ha} /$ season than the combination of other treatments. The great grain yield (GKP) was obtained in the application of manure at 5 tons/ ha combined with 2.5 tons/ha of zeolite, reaching 6.9 tons/ha of rice grain yield.

\section{ACKNOWLEDGMENTS}

Thanks to Mr. Ir. Teddy Sutriadi, M.Si. as the director of Indonesian Agricultural Environment Research Institute for the opportunity given to the author. The authors would also thank the entire GHG team for their assistance in carrying out this research.

\section{REFERENCES}

Aminatun, T., Widyastuti, S.H., Djuwanto. (2014). Pola Kearifan Masyarakat Lokal Dalam Sistem Sawah Surjan Untuk Konservasi Ekosistem Pertanian. Jurnal Penelitian Humaniora, Vol. 19, No.1, April 2014: 65-76

Diacono, M., and Montemurro, F. (2011). Long-term effects of organic amendments on soil fertility. In Sustainable Agriculture Volume 2 (pp. 761-786). Springer, Dordrecht.

Dendooven, L., Patino-Zúniga, L., Verhulst, N., Luna-Guido, M., Marsch, R. dan Govaerts, B. (2012). Global warming potential of agricultural systems with contrasting tillage and residue management in the central highlands of Mexico. Agriculture, Ecosystems \& Environment, 152, 50-58.

Eckhard, B. and Matthias, H. (1997). Adsorption equilibria of methane and tetrafluoromethane and their binary mixtures on silicalite. J. Chem. Soc., Faraday Trans., 1997,93, 1621-1628. DOI: 10.1039/A607399I

Houghton, J.T., Ding, Y., Griggs, D.J., Noguer, M., van der Linden, P.J., Dai, X., Maskell, K. and Johnson, C.A. (2001). Radiative forcing of climate change. Climate Change 2001: The Scientific Basis. Contribution of Working Group I to the Third Assessment Report of the Intergovernmental Panel on Climate Change. Cambridge University Press, Cambridge, UK and New York, NY USA (881 pp.).

Hui, K. S. and Chao, C. Y. H. (2008). Methane emissions abatement by multi-ion-exchanged zeolite A prepared from both commercialgrade zeolite and coal fly ash. Environmental science \& technology, 42(19), 7392-7397.

Joseph, L. Z., Anthony, L. H. and Dendy, S. (1983). Methane adsorption on $5 \mathrm{~A}$ molecular sieve in the pressure range 4 to $690 \mathrm{kPa}$. Ind. Eng. Chem. Process Des. Dev., 1983, 22 (1), pp 172-174. DOl: $10.1021 / \mathrm{i} 200020 \mathrm{a030}$

Khalil. M. A. K., Rasmussen, R.A., Wang, M. X. and Ren, L. (1991). Methane Emission from Rice Fields in China. Environment Science Technology. 25: 979-981.

Al - Jabri, M. (2009). Peningkatan Produksi Tanaman Pangan Dengan Pembenah Tanah Zeolit Dimuat dalam Tabloid Sinar Tani, 7 Januari 200

Marwasta, D. dan Priyono, K. D. (2007). Analisis Karakteristik Desadesa Pesisir di Kabupaten Kulon Progo. Forum Geografi, Vol 21 No. 1, Juli 2007: 57-68

Mukesh, K. A., Quan, W., Wang, H. H., Xiuna, R., Altaf, H. L., Amanullah, M., Amjad, A., Feng. S., Ronghua, L. and Zengqiang, Z. (2016). Influence of zeolite and lime as additives on greenhouse gas emissions and maturity evolution during sewage sludge composting. Bioresource Technology 216 (2016) 172-181

Mulyadi dan Wihardjaka, A. (2014). Emisi Gas Rumah Kaca dan Hasil Gabah dari Tiga Varietas Padi pada Lahan Sawah Tadah Hujan Bersurjan. Jurnal Penelitian Pertanian Tanaman Pangan Vol. 33 No. 2. Hal 116-121

Mosier, A.R., Bronson, K. F., Freney, J. R. and Keerthisinghe, D.G. (1994). Use nitrification inhibitors to reduce nitrous oxide emission from urea fertilized soils. $\underline{\ln } \mathrm{CH}_{4}$ and $\mathrm{N}_{2} \mathrm{O}$ : Global Emissions and Controls from Rice Field and Other Agricultural and Industrial Sources. NIAES. Pp. 187 - 196. 

146 Planta Tropika: Jurnal Agrosains (Journal of Agro Science)
Vol. 7 No. 2 / August 2019

Myrsini, K., Antoniou., Evmorfia, K., Diamanti., Apostolos, E., Alfonso, P., Konstantinos, D., Federica, C., Enrico, M., Dimitrios, G. and Raffaele, G. A. (2014). Methane storage in zeolite-like carbon materials. Microporous and Mesoporous Materials 188 (2014) $16-22$

Ramesh, K. and Reddy, D. D. (2011). Zeolites and their potential uses in agriculture. In Advances in agronomy (Vol. 113, pp. 219-241). Academic Press.

Sepaskhah, A. R. and Barzegar, M. (2010). Yield, water and nitrogenuse response of rice to zeolite and nitrogen fertilization in a semi-arid environment. Agricultural Water Management, 98(1), 38-44.

Wihardjaka, A. dan Indratin. (2002). Hasil padi gogorancah pada tanah bertekstur lempung dengan perlakuan olah tanah dan kotoran sapi. Prosiding Seminar Nasional Sistem Produksi Pertanian Ramah Lingkungan. Pusat Penelitian dan Pengembangan Tanaman Pangan. p. 185-191. 